Discussion Paper No. 11-003

\title{
Costs and Benefits of Inter-departmental
} Innovation Collaboration

\author{
Maarten Cuijpers, Hannes Guenter,
} and Katrin Hussinger

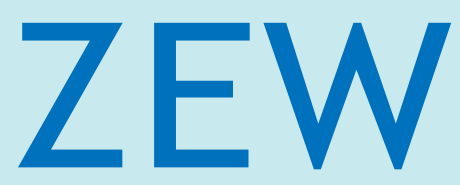

Zentrum für Europäische Wirtschaftsforschung $\mathrm{GmbH}$

Centre for European

Economic Research 
Discussion Paper No. 11-003

\title{
Costs and Benefits of Inter-departmental Innovation Collaboration
}

\author{
Maarten Cuijpers, Hannes Guenter, \\ and Katrin Hussinger
}

Download this ZEW Discussion Paper from our ftp server:

ftp://ftp.zew.de/pub/zew-docs/dp/dp11003.pdf

Die Discussion Papers dienen einer möglichst schnellen Verbreitung von neueren Forschungsarbeiten des ZEW. Die Beiträge liegen in alleiniger Verantwortung der Autoren und stellen nicht notwendigerweise die Meinung des ZEW dar.

Discussion Papers are intended to make results of ZEW research promptly available to other economists in order to encourage discussion and suggestions for revisions. The authors are solely responsible for the contents which do not necessarily represent the opinion of the ZEW. 


\section{Non-technical Summary}

Research on management and organization science has identified inter-departmental innovation collaboration as a mechanism to facilitate corporate innovation performance. Inter-departmental collaboration increases the exchange of information thereby benefiting innovation processes and outcomes. At the same time, inter-departmental innovation collaboration has been identified as a source of increased costs. Costs, such as project delays, can arise because departments set different task priorities and pursue incongruent objectives but also because of differences in educational backgrounds of employees. In the worst case, these differences between departments can cause dysfunctional conflicts that may lead to innovation project terminations. Such costs may absorb the gains generally associated with inter-departmental innovation collaboration.

Drawing from organizational information processing theory, this paper builds and tests hypotheses on the costs and benefits of innovation-related collaboration within firms. Based on a sample of 433 German manufacturing firms we show inter-departmental innovation collaboration to increase process innovation performance, but not product innovation. In line with information processing theory, we submit that process innovation, more so than product innovation, depends strongly on company specific knowledge embedded throughout the organization and the exchange thereof. Our empirical results also detect costs produced by inter-departmental innovation collaboration in terms of project delay and termination. These costs, however, do not affect innovation performance at the firm level. We conclude firms to be well able to balance the costs and benefits of inter-departmental collaboration across their innovation project portfolio. 


\section{Das Wichtigste in Kürze}

Abteilungsübergreifende Zusammenarbeit an innovativen Projekten fördert den Informationsaustausch und kann Innovationsprozesse und deren Ergebnis deutlich verbessern. Andererseits kann abteilungsübergreifende Zusammenarbeit auch Kosten verursachen. Abteilungen haben verschiedene Prioritäten und Zielsetzungen und beschäftigen Mitarbeiter mit unterschiedlichem Berufshintergrund, was die Zusammenarbeit komplizieren und zu Verspätungen in der Projektarbeit führen kann. Im schlimmsten Fall können diese Unterschiede Konflikte verursachen, die letztendlich zum Abbruch von Innovationsprojekten führen. Projektverzögerungen und Projektabbrüche stellen potentielle negative Folgen von abteilungsübergreifender Zusammenarbeit dar, die den Vorteilen der Zusammenarbeit entgegenwirken.

Basierend auf dem betrieblichen Informationsverarbeitungsansatz (,organizational information processing theory“") formulieren und testen wir in dieser Studie Hypothesen über die Vor- und Nachteile von abteilungsübergreifender Zusammenarbeit an innovativen Projekten. Unsere empirischen Ergebnisse zeigen, dass abteilungsübergreifende Zusammenarbeit an innovativen Projekten den innovativen Erfolg von Firmen im verarbeitenden Gewerbe in Deutschland erhöht. Abteilungsübergreifende Zusammenarbeit fördert Prozessinnovationen, jedoch nicht Produktinnovationen. Dies kann daran liegen, dass der Austausch unternehmensspezifischer Informationen für Prozessinnovationen eine größere Rolle spielt als für Produktinnovationen. Unsere Ergebnisse zeigen weiter, dass abteilungsübergreifende Zusammenarbeit Kosten in Form von Projektverzögerungen und Projektabbrüchen verursacht. Da sich diese Kosten jedoch nicht negativ auf den Innovationserfolg des Unternehmens auswirken, schlussfolgern wir, dass Unternehmen sehr wohl dazu in der Lage zu sein scheinen, Kosten und Nutzen von abteilungsübergreifender Zusammenarbeit innerhalb ihres Innovationsportfolios gegeneinander abzuwägen. 


\title{
Costs and Benefits of Inter-departmental Innovation Collaboration
}

\author{
-This paper is forthcoming in Research Policy- \\ Maarten Cuijpers ${ }^{\mathrm{a}}$, Hannes Guenter ${ }^{\mathrm{a}}$ and Katrin Hussinger ${ }^{\mathrm{a}, \mathrm{b}, \mathrm{c}}$ \\ ${ }^{a}$ Maastricht University School of Business and Economics, Department of Organization and \\ Strategy, 6200 MD Maastricht, The Netherlands, Email: \\ m.cuijpers/h.guenter/k.hussinger@maastrichtuniversity.nl \\ ${ }^{b}$ ZEW Centre for European Economic Research, Department of Industrial Economics and \\ International Management, L7,1, 68161 Mannheim, Germany \\ ${ }^{c}$ K.U. Leuven, Department of Managerial Economics, Strategy and Innovation, Naamsestraat \\ 69, 3000 Leuven, Belgium
}

January 2011

\begin{abstract}
Inter-departmental innovation collaboration facilitates innovation performance. At the same time, it has been identified as source of increased coordination costs. Using organizational information processing theory, this paper builds and tests hypotheses on the costs and benefits of innovation-related collaboration within firms. Based on a sample of 433 German manufacturing firms we show inter-departmental innovation collaboration to increase process innovation performance, but also to produce costs in terms of project delay and project termination. These costs, however, do not affect innovation performance at the firm level. This finding suggests firms to be well able to balance the costs and benefits of interdepartmental collaboration across their innovation project portfolio. Theoretical and managerial implications are discussed.
\end{abstract}

Keywords: inter-departmental innovation collaboration, innovation performance, project delay, project termination

JEL Codes: O32, M54, O31 


\section{Introduction}

Innovation is a collective process of idea generation and implementation that builds upon resources, skills, and personnel from different organizational functions (Gibson and Gibbs, 2006; Tatikonda and Rosenthal, 2000a). To facilitate the exchange of innovationrelated information in organizations, scholars and business practitioners have promoted interdepartmental collaboration (see Olson et al., 2001; Tatikonda and Montoya-Weiss, 2001). Inter-departmental collaboration describes the exchange of information and the coordination of activities across interdependent organizational units, such as, research and development (R\&D), marketing, and manufacturing (Eisenhardt and Tabrizi, 1995; Jansen et al., 2009; Song et al., 1997; Tessarolo, 2007; Troy et al., 2008).

Inter-departmental collaboration increases firms' innovation performance (De Luca and Atuahene-Gima, 2007; Swink and Song, 2007; Troy et al., 2008) because it fosters information exchange (Troy et al., 2008), enhances the number of potentially useful ideas (Milliken and Martins, 1996), increases flexibility of the workforce (Troy et al., 2008), and improves functional performance of new products (Olson et al., 2001). However, interdepartmental collaboration is not without drawbacks (Swink and Song, 2007). Collaboration between departments has been associated with negative consequences such as less efficient decision making (Troy et al., 2008) and conflicts over resources and technical issues (Troy et al., 2008), which result in budget overruns (Olson et al., 2001) and project failures (Mishra and Shah, 2009; Swink and Song, 2007). In line with other scholars, we refer to such negative consequences of inter-departmental collaboration as costs. ${ }^{1}$ Hansen (2009), for example, summarized it well: “[Cross-unit] collaboration can deliver tremendous benefits

\footnotetext{
${ }^{1}$ Unless stated otherwise, costs, as used in this paper, are not restricted to monetary expenses, but also include non-monetary expenses, such as time and effort invested in overcoming and dealing with project delays and project failures. For example, project delays create additional coordination demands to replan and reschedule manufacturing and delivery.
} 
(innovative offerings, new sales). But it can also backfire if its costs (including delays stemming from turf battles) prove larger than [...] expected" (p. 84).

While prior research has enhanced our understanding of the costs and benefits associated with inter-departmental collaboration, several gaps remain. One unexplored issue relates to the simultaneous assessment of costs and benefits of inter-departmental innovation collaboration. The majority of research has addressed either the costs of inter-departmental collaboration or its benefits, with most articles focusing on the latter (for a notable exception, see Swink and Song, 2007). Another gap concerns the firm-level effects of inter-departmental innovation collaboration. While some research exists that links inter-functional integration and innovation performance of firms (e.g. De Visser et al., 2010; Perks, 2007; Song et al., 2006), the majority of research has investigated innovation-related collaboration at the project level (Koufteros et al., 2002). This research treats innovation projects as isolated entities, that exist independent of other projects (Engwall, 2003). Firm-level research shifts the focus from single projects to portfolios of innovation projects managed within one firm (see Cooper et al., 2001). ${ }^{2}$

To derive hypotheses on inter-departmental innovation collaboration and its performance effects at the firm level, we draw from organizational information processing theory (OIPT; Daft and Lengel, 1986; Tushman and Nadler, 1978). OIPT has served as one of the main theoretical frameworks for understanding innovation (e.g. Tatikonda and Rosenthal, 2000b; West, 2000). Mishra and Shah (2009), for example, suggested that OIPT is "the primary theoretical lens" (p. 325) through which scholars have investigated innovation collaboration. OIPT directs attention to the internal structure of firms and provides a solid

\footnotetext{
2 Given our interest in intra-firm collaboration, we do not survey research on inter-firm innovation collaboration (Lhuillery and Pfister, 2009; Tomlinson, 2010) or studies on the combined effects of internal and external collaboration (Milson and Wilemon, 2002). It is also beyond the scope of this paper to elaborate on the effects of inter-departmental collaboration on performance indicators other than innovation (e.g. Ruekert and Walker Jr, 1987).
} 
theoretical basis to explain how firm structures influence innovation. OIPT, essentially, argues that firms must build internal structures that fit a given task uncertainty; the more uncertain the task, the more flexible the internal structure should be. This is because flexible structures allow processing more information which helps reducing uncertainty. As such, inter-departmental collaboration provides means for coping with the high uncertainty inherent to innovation. OIPT is a useful framework for studying inter-departmental innovation not only because it allows predicting the effects of within-firm collaboration, but also because it explains the mechanisms behind these effects.

OIPT, however, has rarely been used to address the costs of inter-departmental innovation collaboration along with its benefits. In our view, this is surprising given that OIPT explicitly states that inter-departmental collaboration not only has benefits, but also can generate costs (e.g. Tushman and Nadler, 1978). In particular, OIPT indicates that interdepartmental collaboration affords more time and resources and enhances the risk of coordination failure and project delay (West, 2000). We draw upon a sample of 433 German manufacturing firms to test a set of hypotheses derived from OIPT. Our findings largely support our hypotheses in that we find inter-departmental innovation collaboration to facilitate process innovation performance, but also to incur costs in terms of project delays and cancellations.

This research adds to the literature on innovation within firms in several ways. First, in drawing upon OIPT (Tushman and Nadler, 1978), we provide a parsimonious explanation for why inter-departmental innovation collaboration within firms not only has benefits but also induces costs. Second, we explicitly model the costs of inter-departmental collaboration in terms of project delays and terminations. Third, we provide new insights into the relationship between project delays and terminations and innovation performance by adopting 
a firm-level perspective. Scholars focusing on collaboration in individual projects have stated that project delays endanger innovation performance (see Eisenhardt and Tabrizi, 1995; Menon et al., 2002). Our study, in contrast, finds delays and terminations to not harm the overall innovation performance of the firm. This finding illustrates that, on average, managers seem to be well able to balance the costs of inter-departmental collaboration across a portfolio of innovation projects. Fourth, we distinguish multiple dimensions of innovation performance to assess the benefits of inter-departmental collaboration. While prior research on inter-departmental collaboration has mainly focused on product innovation, that is, innovation of the technology in the product, we also assess how inter-departmental collaboration influences process innovation, that is, innovation of the technology used to manufacture the product (Tatikonda and Montoya-Weiss, 2001).

This paper is structured as follows. In section 2, we introduce the main ideas of OIPT before deriving hypotheses on the benefits and costs of inter-departmental collaboration. In section 3, we describe the empirical analysis and the data used in this study. Section 4 presents the empirical results before the last section concludes with a discussion of the theoretical and practical implications of this study.

\section{Conceptual background and hypotheses}

\subsection{Inter-departmental innovation collaboration}

Innovation is a highly uncertain and complex organizational task. Mishra and Shah (2009) stated that "new product development environments are typically characterized by high levels of both uncertainty and equivocality" (p. 325). This involves uncertainties about the technology and the customer demand. In the semiconductor industry, for example, technological uncertainty is high because innovation processes typically consist of 600 and more different steps. If product changes are necessary, this affords to review and possibly 
alter all of these steps (West, 2000). Next to technological uncertainty, uncertainty about customer demand makes it difficult to assess the implications of innovation ex ante which aggravates the innovation process (Atuahene-Gima and Li, 2004).

Given such hazardous conditions, firms need to gather, store, and disseminate large amounts of information in order to generate innovations (Atuahene-Gima and Li, 2004). This affords that firms, first, need to locate the necessary information, which is complicated by the fact that innovation-related information exists in a variety of forms and formats, such as, technical specifications, intellectual property rights, strategic plans, work rules, and market reports (Sheremata, 2000). Second, firms need to learn how to interpret and make sense of information that often is equivocal, uncertain, and contradictory. In other words, the processing of innovation-related information is not only a logistic challenge, but also a challenge in terms of sensemaking (Daft and Lengel, 1986; Tushman and Nadler, 1978; Weick, 1979; West, 2000).

Not all firm structures are equally well suited to cope with such challenges. OIPT (Daft and Lengel, 1986; Galbraith, 1974; Tushman and Nadler, 1978) suggests that the capacity of organizations to reduce uncertainty depends to a large extent upon the way firms are structured. The more bureaucratic and rigid organizational structures are, the more difficult it is for firms to exchange and use large amounts of complex information. More flexible forms of within-firm structures, such as inter-departmental relationships, expand the capacity of work units to exchange and use information more effectively and thus provide better means to cope with uncertainty (Daft and Lengel, 1986; Galbraith, 1973, 1974; Ghoshal et al., 1994; Tushman and Nadler, 1978; West, 2000). While inter-departmental collaboration provides a flexible structure that allows exchanging and integrating information during task 
execution, these benefits of inter-departmental collaboration do not come without costs, as we explain below.

\subsection{Benefits of inter-departmental innovation collaboration}

As Becker and Lillemark (2006) observed, inter-departmental collaboration is strongly motivated by its expected benefits in terms of innovation performance. Innovation performance, in line with prior research, describes the commercial benefits a firm receives from introducing an innovation into the market or from using it within the firm (see Czarnitzki and Hottenrott, 2009; Kirner et al., 2009; Klein and Sorra, 1996; Prajogo and Ahmed, 2006). According to OIPT (Daft and Lengel, 1986), the positive influence of interdepartmental collaboration on innovation is due to the large amount of information that can be processed across departmental boundaries. Because of this relatively high information processing capability, it becomes possible to anticipate downstream risks, such as design incompatibilities or market constraints (Eisenhardt and Tabrizi, 1995). The earlier such risks are identified, the less costly and time-consuming it is to mitigate them. A high information processing capacity also makes it more likely that the innovation actually meets customer needs, since more customer information can be processed.

Empirical evidence provides support for this OIPT based reasoning. Hise (1990) studied 252 manufacturing firms and found inter-departmental collaboration-involving R\&D and marketing — to predict the level of product success. Zeller (2002) conducted research on inter-functional cooperation in the pharmaceutical industry and suggested that strong interfunctional ties between $R \& D$ and marketing are critical to innovation capabilities. De Luca and Atuahene-Gima (2007), similarly, found cooperation among functional unitsincorporating $\mathrm{R} \& \mathrm{D}$, manufacturing, and marketing — to facilitate product innovation performance. While they found no direct effects, their study on 363 firms - in line with 
OIPT — demonstrated cross-functional collaboration to increase innovation performance indirectly through knowledge integration (e.g. information sharing meetings and face-to-face discussions). Love and Roper (2009), eventually, studied UK and German manufacturing plants and found inter-functional collaboration to benefit innovation performance, especially in the rather technical stages of the innovation process, that is, product design, product development, and product engineering. In summary, both conceptual work and empirical findings suggest that inter-departmental collaboration benefits innovation performance. Hence, we suggest:

Hypothesis 1: Inter-departmental innovation collaboration is positively associated with innovation performance.

\subsection{Costs of inter-departmental innovation collaboration}

As indicated above, inter-departmental collaboration, while beneficial in terms of information processing, is not without caveats. From OIPT we derive that besides the benefits of information processing, inter-departmental collaboration absorbs much time and resources because it makes it necessary to integrate different forms of expertise and problemsolving approaches (see West, 2000). In the wording of OIPT, inter-departmental collaboration consumes "more time, effort and energy" (Tushman and Nadler, 1978, p. 618) and is "less amenable to managerial control" (Tushman and Nadler, 1978, p. 618) than less flexible forms of coordination, such as, hierarchies. This is why Tushman and Nadler (1978) urged firms to weigh the "benefits of increased information processing capability" (p. 618) against the "cost of less control and potentially increased response time" (p. 618). Building upon this logic of OIPT, we formulate hypotheses on the relationship between interdepartmental innovation collaboration and project delays as well as project terminations in the following sections. 
2.3.1 Project delays. Project delays denote the degree to which a project is behind schedule (McDonough, 1993). In other words, project delays occur the moment a project does not meet an assigned deadline. While some research suggests inter-departmental collaboration to enhance timeliness of projects (García et al., 2008; Zeller, 2002), there is mounting evidence that inter-departmental collaboration may actually produce, rather than prevent, project delays (Hansen, 2009; Mishra and Shah, 2009; Swink and Song, 2007; West, 2000). Mishra and Shah (2009) stated that inter-departmental collaboration often is "timeconsuming and resource intensive" (p. 327), and Hansen (2009) suggested that interdepartmental collaboration can cause "delays in completing a project or delivering products and services" (p. 85). West (2000), in drawing explicitly from OIPT, argued that bringing together experts from different fields in an attempt to enhance innovation may cause delays because integrating inputs from different knowledge domains poses additional coordination demands. Coordinating and integrating inter-functional input can lead to "informationprocessing breakdown and coordination failure" (West, 2000, p. 352) including "confusion, delay and redundant effort" (West, 2000, p. 352).

Inter-departmental collaboration slows down information processing because departments adhere to different operating principles (Dougherty, 1992), aim at different goals (Swink and Song, 2007), and speak different, technical jargon (Song et al., 1997). Consider for example the marked differences in operating principles between $R \& D$, manufacturing, and marketing. While manufacturing seeks to narrow product lines to gain economies of scale and reduce changeover time, marketing aims for broad product lines in order to satisfy as many customer needs as possible. Similarly, while R\&D gives primacy to continuous perfection of design solutions, manufacturing aims for freezing design specifications relatively early (Song et al., 1997). 
Arguably the most rigorous empirical assessment of the link between interdepartmental collaboration and project delays is provided by Swink and Song (2007). In their study on 467 new product development projects, completed in U.S. high-technology firms, Swink and Song (2007) found marketing-manufacturing collaboration to lengthen project time. While they found cross-unit collaboration to not delay technical development and product testing, inter-departmental collaboration aggravated business and market analysis and significantly slowed down product commercialization, thus lengthening project time. In line with OIPT (Daft and Lengel, 1986) and previous empirical evidence, we suggest:

Hypothesis 2a: Inter-departmental innovation collaboration is positively associated with innovation project delay.

2.3.2 Project termination. Inter-departmental collaboration not only can cause innovation projects to run late, but—because of its conflict potential—can also disrupt ongoing projects and thus increase termination rates of innovation projects. Project termination (also referred to as project cancellation or project failure) is defined as "the discontinuation of a project before it achieves its complete implementation" (Dilts and Pence, 2006, p. 380). Corbett, Neck and DeTienne (2007) estimated that roughly one-third of innovation projects are terminated, which indicates project termination to be a relatively common phenomenon within organizations.

In their seminal paper on OIPT, Daft and Lengel (1986), suggested that because departments have distinct frames of reference and pursue disparate goals, inter-departmental communication can be "complex, ambiguous and difficult to interpret" (p. 564). Organizational members "may be in conflict with respect to data interpretation or its significance for goal attainment" (Daft and Lengel, 1986, p. 556). While conflicts, in some instances, can be productive, inter-functional collaboration, as observed by many scholars, 
often provokes dysfunctional conflicts (Dawes and Massey, 2005; Gebert et al., 2006; Griffin and Hauser, 1992; Xie et al., 1998). Song et al. (2006), for example, suggested that the conflicts experienced in inter-departmental innovation collaboration can lead to poor decision-making and may disrupt work patterns. To the extent that such dysfunctional conflicts escalate, inter-departmental relationships may be damaged severely and innovation projects may come to a halt. Instead of engaging in synergistic communication, departments may engage in turf fights making communication and cooperation troublesome (Gebert et al., 2006; Hansen, 2009). Such difficulties are likely to hinder project progress and increase the risk of project termination. Based upon these findings, we submit:

\section{Hypothesis 2b: Inter-departmental innovation collaboration is positively associated} with innovation project termination.

\subsection{Delays, termination and innovation performance}

While longer project cycles need not to undermine innovation (Griffin, 1997), project delays are detrimental to innovation performance. McKinsey \& Company, a management consultancy, concluded from a study of high-technology products that "products that were six month late in entering the market, but were within budget, earned 33 percent less over a fiveyear period than they would have if on time" (Eisenhardt and Tabrizi, 1995, p. 85). Firms, on the contrary, that exceeded the budget significantly, but entered the market on time, only experienced a loss in profitability of $4 \%$ for that product (Eisenhardt and Tabrizi, 1995). Menon et al. (2002), in view of these findings, suggested that "the damaging effects of lost sales on account of delayed shipment to market are overcome only rarely through a superior product" (p. 324). Hendricks and Singhal (2008) provided further support for the view that project delays impair innovation performance. They studied product introduction delays in nearly 450 firms and found delays to substantially and negatively impact profitability. 
These negative ramifications of project delays are because firms are less likely to benefit from first-mover advantages, such as, higher margins, more time to establish industry standards, or privileged access to distribution channels (Menon et al., 2002; Tatikonda and Montoya-Weiss, 2001). Also, customers waiting for late products may decide to cancel their order, reducing sales and possibly strengthening competitors (Hendricks and Singhal, 2008). Next, firms that deliver products late may face penalty costs, often predetermined between firms and customers (Hendricks and Singhal, 2008). Eventually, firms may need to invest resources and time in rebuilding firm reputation that suffered from project delays. Overall, we submit that there is mounting evidence to believe that project delays undermine innovation performance and suggest:

\section{Hypothesis 3a: Innovation project delay is negatively related with innovation performance.}

Sometimes, innovation projects need to be abandoned before they are completed. While the termination of a project occasionally might be the only economically sensible thing to do (Corbett et al., 2007; Dilts and Pence, 2006), this can have substantial negative consequences. Iacovou and Dexter (2005) gave the example of an order entry system project that failed resulting in lost sales of $\$ 50$ million. Marwa and Zairi (2008) conducted a literature review and found several studies that specified innovation failure as the reason for the demise of firms. In more general terms, it appears that ,project cancellations are very costly, with damages exceeding millions of dollars“ (Iacovou and Dexter, 2005, p. 184).

The negative consequences of innovation project cancellations mainly stem from the fact that a large part of the resources invested in the innovation project cannot be recovered or put into alternative use. Resources include, amongst others; machinery, equipment and infrastructure, as well as R\&D, design, and engineering (Archibugi et al., 1995). While some 
of the physical infrastructure may be reused in future innovation projects, most of the R\&D investments are basically not reversible and thus sunk, partly because the salary of R\&D personnel represents the largest share of $R \& D$ expenses (Stifterverband, 2010). The fact that means invested in terminated projects might have been used more productively elsewhere should be reflected in an inferior innovation performance of the firm. Moreover, project failures are costly in that they have dysfunctional outcomes at the individual level (Shepherd and Cardon, 2009). To the extent that organizational members identify with the innovation, project failure can create a negative emotional reaction in individuals that prevents learning, stifles entrepreneurial thinking, and undermines risk-taking behavior, behaviors critical to innovation (Shepherd and Cardon, 2009; Shepherd and Kuratko, 2009). Overall, this leads us to suggest:

Hypothesis 3b: Innovation project termination is negatively related with innovation performance.

\section{Data}

We investigate the costs and benefits of inter-departmental innovation collaboration using data from the Mannheim Innovation Panel (MIP), a survey which since 1992 has been conducted annually by the Centre for European Economic Research (ZEW) on behalf of the German Federal Ministry of Education and Research (BMBF). The MIP is the German part of the Community Innovation Survey (CIS) of the European Commission. The CIS is in accordance with the OSLO manual, which defines international guidelines for collecting innovation data from the business sector (OECD-Eurostat, 2005). ${ }^{3}$ The MIP provides comprehensive information about innovation activities of German firms, including various measures for firms' innovation performance and factors hampering innovation.

\footnotetext{
${ }^{3}$ For a detailed description of the CIS, see for example Eurostat (2004).
} 
The MIP survey 2003 constitutes the cross-sectional database for our empirical analysis. ${ }^{4}$ We restrict the sample to manufacturing firms and exclude firms that were not engaged in product and/or process innovation over the period 2000-2002. The 2003 questionnaire asks firms about innovation-related collaboration between different departments ( $R \& D$, marketing, production, purchasing, controlling, and human resource management). Inter-departmental innovation collaboration is measured via seven items describing interdepartmental collaboration activities, as for example; joint development of innovation strategies, open communication of innovation-related ideas and concepts, mutual support in case of problems related to innovation projects, and temporary innovation-related personal exchange between departments. Firms needed to indicate whether they engaged in any of these kinds of inter-departmental innovation collaboration. Based on this information, we define a binary variable indicating whether a firm engaged in at least one form of interdepartmental innovation collaboration.

In order to measure the costs of inter-departmental innovation collaboration we assess innovation project delays and innovation project terminations. The survey 2003 asks the firms whether they experienced any delays or terminations regarding innovation projects. Both variables are binary indicators. The project delay variable, for instance, takes the value 1 if a firm has innovation projects that are completed later than originally planned.

In order to measure the benefits of inter-departmental innovation collaboration the survey offers a variety of different innovation indicators tapping product as well as process innovation, a distinction often deemed critical (Pittaway et al., 2004; Roper et al., 2008). Our measures of product and process innovation correspond to metrics conventionally used in the

\footnotetext{
${ }^{4}$ We can only use the 2003 data because the questions of the MIP change every year, and 2003 is the only wave containing information about inter-departmental innovation collaboration.
} 
literature (De Visser et al., 2010; Love and Roper, 2009). To measure the outcome of product innovation we employ two distinct measures. First, we use sales from products new to the market. As Rammer, Czarnitzki, and Spielkamp (2009) explained, this does not necessarily mean that the product is the first of its kind worldwide because markets often are regional in nature. Second, we use sales from products new to the firm, that is, product line novelties and improved products (Subrahmanya, 2005).

To assess the outcome of process innovations, we use two distinct indicators. First, we measure cost reduction due to process innovation. This kind of process innovation is likely to increase price competitiveness of firms thus providing a competitive advantage (Rammer et al., 2009). Second, we assess sales due to increased product quality that was reached through process innovation because high quality products provide means by which a firm can set itself apart from competitors.

We use the 2005 survey data to define our dependent variables based on the firms' innovative output in the period 2003-2004. Using values of the dependent variables with a lead of two years avoids that our results are driven by reverse causality, in the sense that innovation performance drives collaboration activities. Hence, our sample only includes firms that responded to the survey at both times-2003 and 2005. In total, this leaves us with a sample of 433 innovative firms in German manufacturing, 67\% of which engage in interdepartmental innovation collaboration. Table 1 shows descriptive statistics for the variables used for the empirical analysis.

Insert Table 1 about here

Table 1 summarizes firm characteristics and innovation measures for firms that engage in inter-departmental collaboration compared to firms that do not engage in collaboration. First of all, it appears that the average firm only earns a relatively small share of its total sales 
with innovations. The most significant part stems from sales with products new to the firm, which reaches an average of $26 \%$ of the total sales for collaborating firms. Interestingly, there is no difference between firms that engage in inter-departmental innovation collaboration and others in terms of shares of sales with products new to the market or new to the firm.

Differences exist, however, for process innovation outcomes in terms of cost reductions and sales due to quality improvements. This suggests inter-departmental collaboration to be more important for process innovation than for product innovation. In the empirical section we investigate this relationship further in a multivariate setting. We use the logarithms of our innovation performance measures as dependent variables in our empirical model in order to account for the skewness of the innovation outcome variables.

Regarding the costs of inter-departmental innovation collaboration, Table 1 shows that $57 \%$ of the collaborating firms experienced project delays and $33 \%$ of collaborating firms had to terminate innovation projects. Firms that engage in inter-departmental collaboration experience significantly more project delays and terminations than others. On average, firms that engage in inter-departmental collaboration have seven times the risk of project delays and sixteen times the risk of terminations as non-collaborating firms. ${ }^{5}$

In addition, we use a set of control variables. We expect firm size and R\&D intensity to be the main determinants of innovation outcomes. Firm size is measured in terms of labor force. In order to account for the skewness of the firm size distribution, we use the logarithm of the number of employees in our empirical specification. Firm size reflects innovation capacity because large firms profit from economies of scale and scope and are more likely to realize complementarities between different departments (Galbraith, 1952). Prior research on

\footnotetext{
${ }^{5}$ For both indicators, that is, delays and cancellations, $\mathrm{X}^{2}$-tests show that their distribution across collaborating and noncollaborating firms is different at the $1 \%$-level of statistical significance.
} 
process innovation indeed showed the investments in process innovation to increase with firm capacity (Cohen and Klepper, 1996; Fritsch and Meschede, 2001). Investment in R\&D is the most important input for innovation, in particular for product innovation. We normalize this variable by the firm's total sales to assess $R \& D$ intensity of the firm, in order to avoid biases due to a high correlation with firm size.

Firm size and R\&D intensity are also expected to impact the risk of project delays and terminations. Large, $R \& D$ intense firms typically engage in more innovation projects; this naturally increases the risk of project delays and terminations. At the same time, large firms typically have a better organization structure and superior access to capital markets which can reduce the likelihood of project delays and terminations. Table 1 shows that firms with collaboration activities do not differ from others in terms of size, $R \& D$ expenditure, and $R \& D$ intensity. This makes us confident that our empirical findings are not driven by systematic differences in the main determinants of innovation between collaborating and noncollaborating firms.

Furthermore, we use a dummy for firms being part of a firm group because the extent to which firms collaborate within a firm consortium may influence their propensity to engage in inter-departmental collaboration. This is because the more firms source innovation-related knowledge through external relationships, the less they may engage in intra-firm collaboration (Cohen and Levinthal, 1990; Roper et al., 2008). The descriptive statistics indeed demonstrate the share of firms that belong to a firm group to be much higher in firms that do not engage in inter-departmental innovation collaboration.

Another control variable is the firm's specialization in the product market. We use the share of sales from the firm's main product as a proxy. We expect that firms with a strong focus on one product line can benefit more from inter-departmental collaboration than 
diversified firms. This is because diversified firms, more so than single-product businesses, rely on multiple innovation routines and procedures, which makes it more difficult to exploit cross-project synergies (see Bercovitz and Mitchell, 2007).

Moreover, we control for firm age and firm location in East Germany. We control for firm age because firms gain technological and product-market experience over time, which may increase innovation performance (Nerkar and Roberts, 2004). Further, we use a dummy to control for firm location in the Eastern part of the country because of Germany's turbulent past. With the fall of the Berlin wall in 1989, East Germany-formerly a planned economywas transformed into a market economy. Recent studies find East German firms to still lack behind their West German counterparts in terms of innovativeness (Czarnitzki and Kraft, 2006) and productivity (Czarnitzki, 2005). Furthermore, we include four industry dummies in our regressions. Eventually, we assess the share of R\&D employees outside the R\&D department. It appears that collaborating firms, compared to non-collaborating firms, have significantly more R\&D employees working in other departments.

\section{Empirical Results}

The empirical analysis investigates the costs and benefits of inter-departmental innovation collaboration. The following equations describe the model tested:

$$
\begin{aligned}
& \text { delay }_{i t}=\alpha_{0}+\alpha_{1} * \operatorname{coll}_{i t}+\alpha_{2} * X_{i t}+u_{t} \\
& \text { termination }_{i t}=\beta_{0}+\beta_{1} * \operatorname{coll}_{i t}+\beta_{2} * X_{i t}+v_{t} \\
& \text { inno }_{i, t+2}=\gamma_{0}+\gamma_{1} * \operatorname{coll}_{i t}+\gamma_{2} * \text { delay }_{i t}+\gamma_{3} * \text { termination }_{i t}+\gamma_{4} * X_{i t}+w_{t+2}
\end{aligned}
$$

First, we test whether there are costs of collaboration in terms of project delays and terminations. Eq. (1) and Eq. (2) specify the relationship between inter-departmental innovation collaboration (coll) and project delays (delay) and terminations (termination). Whereas $X$ represents a set of control variables, $u$ and $v$ are the error terms of the empirical 
models. Hypothesis $2 \mathrm{a}$ and $2 \mathrm{~b}$ predict that inter-departmental innovation collaboration is positively related to project delays and terminations, which—if confirmed—would be visible in a positive sign of the estimated coefficients $\alpha_{1}$ and $\beta_{1}$.

Second, we assess how inter-departmental collaboration and its costs influence innovation performance. Eq. (3) specifies the relationship between inter-departmental collaboration, project delays, terminations, and the innovation outcome (inno). The innovation variable is used with a two years lead to avoid endogeneity issues. Note that we estimate Eq. (3) for the four different dependent variables that measure different dimensions of a firm's innovation outcome (as described in the previous section). As before, $X$ depicts a set of control variables and $w$ specifies the error term of the empirical model. A positive coefficient $\gamma_{1}$ would reflect a positive relationship between inter-departmental collaboration and the outcome of innovation-as predicted by hypothesis 1 . Negative coefficients $\gamma_{2}$ and $\gamma_{3}$ would show that project delays and terminations-reflecting the costs of inter-departmental collaboration-have a negative impact on the outcome of innovation as suggested in hypotheses $3 \mathrm{a}$ and $3 \mathrm{~b}$. The next subsections provide details on the estimation of Eq. (1) to Eq. (3) along with the empirical findings.

\subsection{Costs of inter-departmental collaboration}

In order to test whether inter-departmental innovation collaboration incurs costs in terms of project delays and terminations we run a series of probability models for Eq. (1) and Eq. (2). Table 2 shows the results. The first two columns present standard probit models for both dependent variables. The results show that firms that engage in inter-departmental innovation collaboration are significantly more likely to experience project delays and project terminations. The magnitude of the effect is not negligible as the marginal effects at the means of all other variables show. A discrete change from a value of 0 to 1 in the 
collaboration variable increases the likelihood of project delays by $50 \%$ points at the means of all other variables. Regarding project termination a discrete jump in inter-departmental collaboration increases the termination probability by $31 \%$ points. Given that, on average, $41 \%$ of the firms in our total sample experience delays and $23 \%$ project terminations, this is a sizeable impact.

With regard to the control variables, Table 2 shows that firm size has a significant impact on project delays and terminations. More specifically, the effect of firm size on project delays and terminations is curvilinear. The likelihood of project delays and terminations decreases with firm size up to a certain point. Beyond a certain number of employees, however, firm size increases the risk of project delays and terminations.

Eventually, we find tentative evidence for a positive relationship between $R \& D$ intensity and project delays. This suggests that the larger the firm's innovation intensity is, the more likely project delays are. Firm age also influences project delays in that the older a firm gets, the less likely project delays become. Another interesting finding is that firms with a concentrated product portfolio are less likely to suffer from project delays. Moreover, East German firms are less likely to experience project delays. There is no effect of firm age, focus, and firm location on the probability of project terminations though. A final interesting observation is that firm characteristics are relatively weak predictors for project terminations.

One characteristic of the standard probit model is that it assumes homoscedasticity of the error terms. In case this assumption is violated, the estimated coefficients are inconsistent (Greene, 2005). We tested for heteroscedasticity with regard to four firm size dummies and five industry dummies. Heteroscedasticity was rejected for both equations. ${ }^{6}$

\footnotetext{
${ }^{6} \mathrm{X}^{2}$-tests cannot reject the null hypothesis that the error variances are all equal for both probit models. The $\mathrm{X}^{2}$-statistics are 12.00 for the probit estimation for project delays and 10.23 for the project termination estimation.
} 
A remaining problem with the simple probit models for project delays and terminations is that our main variable, the inter-departmental innovation collaboration dummy, may be subject to reverse causality; firms may engage in inter-departmental collaboration because they experience project delays and terminations. In order to exclude this interpretation we apply instrumental variable (IV) probit regressions that treat the interdepartmental collaboration dummy as endogenous. The challenge for the application of IV approaches is finding a convincing instrumental variable that correlates with the suspected endogenous variable but not with the dependent variable. We use the share of $R \& D$ employees outside the R\&D department as an instrument for collaboration because the allocation of R\&D employees across different departments is assumed to foster interdepartmental innovation collaboration, but to not influence project delays and project terminations. Our instrumental variable influences inter-departmental collaboration because R\&D experts often can only obtain important technical information from other experts-not from non-technical personnel-irrespective of their departmental affiliation (Allen et al., 2007). We do not expect the share of $R \& D$ employees outside the $R \& D$ department to influence project delays and terminations because information processing between samefunction personnel, such as R\&D experts, is typically less problematic than inter-functional communication, since they speak the same technical language (Moenaert and Souder, 1996).

We conduct statistical tests on the validity and relevance of the instrumental variable. We follow Rivers and Vuong (1988) to test, in a first step, whether inter-departmental collaboration is indeed endogenous in the delay and termination equation. Technically, this test implies a regression of the collaboration dummy on the instrumental variable and all other regressors included in the probit model. In a second step, the predicted residuals from these regressions are included in the probit models for delay and termination respectively (Wooldridge, 2002). The estimated coefficient for the residual is the test statistic for the null 
hypothesis of exogeneity of the collaboration dummy. We can reject exogeneity of interdepartmental innovation collaboration regarding project delays and terminations at the $1 \%$ level of statistical significance.

Staiger and Stock (1997) emphasize that endogeneity tests can be misleading in case of weak instruments. If instruments are weak the correlation between the instrumental and the endogenous variable may be inflated because of other control variables. Staiger and Stock (1997) suggest evaluating the partial correlation of the instruments and the endogenous variable as a countermeasure. As a rule of thumb they suggest that the partial F-statistic for the instrumental variable in the first-step regression needs to exceed the value of 10 to ensure that the instruments are not weak. We find an F-statistic of 47.67, which signals that our instrument is not weak.

Table 2 presents the results for the IV probit models for both equations in column 3 and 4. The results of the IV regressions are very similar to the ordinary probit models. Interdepartmental collaboration increases the likelihood of project delays and terminations, but the estimated coefficients for the control variables lose in significance. In conclusion, our findings support hypotheses $2 \mathrm{a}$ and $2 \mathrm{~b}$, suggesting inter-departmental innovation collaboration to produce costs in terms of project delay and termination. ${ }^{7}$

Insert Table 2 about here

\footnotetext{
${ }^{7}$ A remaining problem is that collaborating firms may be more likely to engage in risky innovation projects than noncollaborating firms. Our data set does not allow us to directly address this problem because we lack information on the different types of innovation projects firms engage in. However, the data set provides information on problems firms face during the innovation process. Three of these indicators can serve as proxies for the riskiness of innovation projects, that is; whether firms suffer from a lack of financing; whether they miss technical information; and whether they miss market information. We used t-tests to test for potential differences between collaborating and non-collaborating firms but found no significant differences. Based on this finding and given the absence of direct indicators for project uncertainty, we assume that there is no difference in the degree of uncertainty of innovation projects of collaborating and non-collaborating firms.
} 


\subsection{Benefits of inter-departmental collaboration}

As described in the data section we use four different innovation performance indicators; two of them focus on the effects of product innovation and two measure the effects of process innovation. We use them with a two years lead to avoid endogeneity of our main variables. ${ }^{8}$ The most important regressors in our model are the binary variable indicating inter-departmental innovation collaboration and the binary indicators for project delays and terminations. We use tobit models to estimate Eq. (3) thereby taking into account that the dependent variables are censored for firms that have no innovation sales. ${ }^{9}$ Tobit models, like probit models, produce inconsistent estimates if homoscedasticity is erroneously assumed. Likelihood ratio tests show that heteroscedasticity regarding four firm size dummies and five industry dummies cannot be rejected at any convenient level of statistical significance for four out of the five models. Hence, we apply heteroscedastic tobit models. Table 3 presents the results.

Insert Table 3 about here

The findings in Table 3 show that inter-departmental collaboration has a positive effect on the process innovation-related outcome measures. Collaborating firms profit from sales due to quality improvements and from cost reductions due to process innovations.

\footnotetext{
${ }^{8}$ Instrumental variables regressions were not possible because we would have had to instrument three variables, project delays, project terminations, and inter-departmental collaboration. The survey, however, did not provide appropriate instruments to separate these three different variables. In order to show robustness of our results we also estimated the delay equation, the termination equation, and the respective innovation equation jointly. The innovation variables are defined as dummy variables that take the value of one if the innovation outcome measure is larger than zero. This equation system is a recursive model that can be estimated as a trivariate probit model (Greene, 1987). The results are robust regarding the effect of inter-departmental innovation collaboration on delays, terminations, and the different innovation measures. Also, the findings for the cost variables on our innovation measures confirm the findings presented in section 4.2. Results are available on request from the authors.

${ }^{9}$ Note that although our sample includes only innovating firms, the innovation sales variables can take the value zero. Innovators are defined as firms that have engaged in process or product innovation over the past three years (see section 3 ). It might well be the case that the innovation activities of these firms did not generate any innovation sales or cost reductions in our period of interest. The fact that our dependent variables relatively frequently take the value zero is because we do not focus on the overall innovation sales of firms, but distinguish between different types of innovation sales. A firm might, for instance, realize sales with improved products but fail to generate sales with products that are new to the market in the period of interest.
} 
Again, we see that the impact of inter-departmental innovation collaboration is nonnegligible. The average firm in our sample gains 15,260 Deutsche Mark ${ }^{10}$ (DM) additional sales due to quality improvements at the means of all other variables. This equals a gain in sales related to quality improvements of $1.6 \%$ points. Regarding cost savings due to process innovation, an average firm in our sample gains about 10,870 DM at the mean of all other variables, which translates into cost savings of $1 \%$ at the mean. Concerning the product innovation-related sales, we find that inter-departmental innovation collaboration does not support sales from innovations new to market nor does it foster sales with products new to the firm. In conclusion, these results provide only partial support for hypothesis 1 . Instead of impacting innovation performance in general, we find inter-departmental collaboration to only increase process innovation performance.

Focusing on project delays and terminations, our regression results show that these events do not undermine innovation performance. This finding, which is consistent across all four innovation performance measures, contradicts prior research on project delays and terminations (e.g. Hendricks and Singhal, 2008). We submit these differences to be largely due to differences in the level of analysis; while our study focused on the firm level, the majority of prior research has been at the project level. In conclusion, we do not find empirical support for hypotheses $3 \mathrm{a}$ and $3 \mathrm{~b}$, predicting project delay and termination to undermine innovation performance.

Regarding the control variables, we find differences in effects on product and process innovation. While R\&D intensity is key to product innovation, it does not facilitate process innovation outcomes. Similarly, while firm size —used as a measure for innovation capacity-is important to product innovation success, it does not trigger process related

\footnotetext{
${ }^{10} 1$ "Deutsche Mark" equals approximately 0.51 Euro.
} 
quality improvements. However, we find firm size to influence process related cost reductions. This is a typical pattern because firms need to grow to build up a product portfolio before they start improving their production process (Cohen and Klepper, 1996; Fritsch and Meschede, 2001).

Another interesting finding is that East German companies—while less successful in terms of cost reduction-generate more sales due to quality improvements than their West German counterparts. This can be explained by their turbulent history which has resulted in distinct industry and production structures in the eastern part of the country. Furthermore, we find that the more focused firms are-in terms of product portfolio - the more likely they are to benefit from cost reductions due to process improvements. Eventually, firm age and group membership have no effect on any of the innovation outcome variables.

\section{Discussion}

Drawing from OIPT (Daft and Lengel, 1986; Tushman and Nadler, 1978), this study assessed costs and benefits of inter-departmental innovation collaboration. While prior research has assessed either costs or benefits of inter-departmental collaboration, we investigate both—costs and benefits— simultaneously (see Swink and Song, 2007). Our findings for 433 German manufacturing firms partly confirm our hypotheses. Interdepartmental innovation collaboration, on the one hand, fosters process innovation as evident from cost reductions and increased sales from higher quality products. On the other hand, inter-departmental innovation collaboration also generates costs in terms of unplanned project delay and termination, which is in line with our expectations. We find these collaboration costs to not negatively affect overall innovation performance, which is contrary to our hypotheses. 


\subsection{Implications for theory}

Our findings extend prior research in that we find inter-departmental collaboration to influence product and process innovation differently. Inter-departmental collaboration benefits process innovation outcomes but not the results of product innovation. It appears that product innovation primarily depends on the $R \& D$ intensity of the firm. Why might interdepartmental collaboration benefit process but not product innovation? We suggest that this is due to differences in the kind of information critical for product and process innovation (see De Meyer, 1985; Roper et al., 2008).

Product innovation is externally oriented in that it has a market focus and is customer driven. Product innovation, more so than process innovation, relies on information from sources external to the firm such as scientific journals and reports, and external contacts of R\&D scientists (Damanpour, 2010; De Meyer, 1985; Martínez-Ros, 1999). Process innovation, in contrast, is "pre-eminently company specific" (De Meyer, 1985, p. 320) because the focus is on firm-specific, internal processes, and hence affords intimate knowledge of the structure and the systems of an organization (Damanpour, 2010; De Meyer, 1985; Gopalakrishnan et al., 1999; Martínez-Ros, 1999). Gopalakrishnan et al. (1999) hypothesized and found that process innovations, more so than product innovations, are tightly coupled with other organizational processes and afford members throughout the organization to be in contact with each other when implementing an innovation. These conceptual and empirical arguments_-suggesting process innovation to rely on information embedded throughout the organization — may well explain why we find inter-departmental collaboration to be more important for process than for product innovation. ${ }^{11}$

\footnotetext{
${ }^{11}$ Note that one may argue that external factors, such as competition or other market forces, affect cost reduction to a lesser extent than they influence product innovation related sales. This explanation, however, appears not to be consistent with the
} 
Regarding the costs of inter-departmental innovation collaboration, we find evidence for inter-departmental collaboration to produce both project delays and terminations. This, as OIPT (Daft and Lengel, 1986) suggests, reflects the relatively high coordination costs of flexible within-firm structures such as inter-departmental collaboration (Tushman and Nadler, 1978). The fact that our findings are consistent across the different cost measures (i.e. project delay and project termination) used in this study increases confidence in our results. Interestingly, the costs of inter-departmental innovation collaboration (i.e., project delays and terminations) do not reduce innovation performance. This finding differs from previous findings in which, for example, delays have been demonstrated to negatively affect firm performance (Eisenhardt and Tabrizi, 1995; Hendricks and Singhal, 2008; Menon et al., 2002). Eisenhardt and Tabrizi (1995) summarized research that found that products introduced late to the market earned $33 \%$ less than they would have if introduced timely to the market. We suggest this difference in findings to be due to differences in the level of analysis. While prior research has mainly assessed innovation performance at the project level (see Koufteros et al., 2002; Perks, 2007), we measured innovation performance at the firm level. We conclude that while project level studies can lead to new insights on project management, these findings do not necessarily hold at the firm level. The fact that we find no evidence for the costs of inter-departmental collaboration on innovation performance suggests that, on average, firms seem to be well able to balance the costs and benefits of interdepartmental collaboration. Thus, the overall effect of inter-departmental collaboration on firms' innovation performance appears to be positive.

finding that inter-departmental collaboration influences both process innovation measures, that is, cost reduction and sales due to quality improvements, to a comparable extent. 


\subsection{Managerial implications}

The practical implications of our study are straightforward. In order to boost innovation performance, managers need to provide infrastructure and resources needed for inter-departmental collaboration. Opportunities are plentiful; managers should facilitate the transfer of best practices between departments; invest in collaborative information and communication technologies; and invest in shared meeting space in order to increase the number of encounters between members of different departments and thus information exchange (Allen and Henn, 2006).

Our findings indicate that inter-departmental collaboration is important for process but not necessarily for product innovation. Hence, managers might gain most from adopting a dual strategy. In early stages of the technology lifecycle where no dominant design yet exists, investments in product innovation may generate most profits (Adner and Levinthal, 2001). However, once a dominant design emerges and an industry matures, firms may be better off in investing in process innovations instead (Adner and Levinthal, 2001). Thus, managers need to foster inter-departmental collaboration especially in late technology lifecycle stages; in early stages of the technology lifecycle, managers may generate higher returns on innovation by investing primarily in $R \& D$ related product innovations.

However, when investing in inter-departmental innovation collaboration, managers need to remember that inter-departmental collaboration is likely to tax their patience and may result in unwanted project delays and project terminations. The risk of delays and terminations is higher with inter-departmental innovation collaboration; still, this should not prevent firms from innovating across departmental boundaries given its potential benefits. The fact that we do not find any negative feedback from project delays and terminations on 
any innovation performance measure indicates that mangers are well able to balance the costs of collaboration against its benefits in managing their innovation project portfolios.

\subsection{Limitations and future directions}

Despite the contributions of this study, it is important to reflect upon its limitations. One is that we only used dummy variables to measure project delays and terminations. However, the fact that our findings are consistent across both cost dimensions increases our confidence in the project delay and termination measures. For future research, it would be desirable to have more detailed information on project delays and terminations, such as, the number of projects that were delayed or cancelled per firm, and the investments made in each of these projects. It would also be interesting to know how the cancellation of projects influences future innovation efforts. While it is generally agreed that project termination is necessary to limit the waste of resources that might be used more productively in other projects (Corbett et al., 2007; Dilts and Pence, 2006; Green et al., 2003), it is unclear whether firms learn from such termination experiences. More specifically, it is unclear whether and how termination experiences influence the success of future innovation projects, a question that holds much potential for research.

Furthermore, because we needed to rely upon a dummy variable to measure interdepartmental innovation collaboration, we gained only limited insights into the exact mechanisms of this type of collaboration. A first step towards a more detailed analysis of the mechanisms of inter-departmental innovation collaboration would be to simultaneously assess inter-departmental collaboration at the project and the firm level, as Perks (2007) indicated. While methodologically challenging, such multi-level studies would help break new ground in the research on inter-departmental innovation collaboration. 


\section{Literature}

Adner, R., Levinthal, D., 2001. Demand heterogeneity and technology evolution: implications for product and process innovation. Management Science 47, 611-628.

Allen, J., James, A.D., Gamlen, P., 2007. Formal versus informal knowledge networks in R\&D: a case study using social network analysis. R\&D Management 37, 179-196.

Allen, T.J., Henn, G., 2006. The Organization and Architecture of Innovation: Managing the Flow of Technology. Butterworth-Heinemann, London.

Archibugi, D., Evangelista, R., Simonetti, R., 1995. Concentration, firm size and innovation: evidence from innovation costs. Technovation 15, 153-163.

Atuahene-Gima, K., Li, H., 2004. Strategic decision comprehensiveness and new product development outcomes in new technology ventures. Academy of Management Journal 47, 583-597.

Becker, M.C., Lillemark, M., 2006. Marketing/R\&D integration in the pharmaceutical industry. Research Policy 35, 105-120.

Bercovitz, J., Mitchell, W., 2007. When is more better? The impact of business scale and scope on long-term business survival, while controlling for profitability. Strategic Management Journal 28, 61-79.

Cohen, W.M., Klepper, S., 1996. A reprise of size and R\&D. The Economic Journal 106, 925951.

Cohen, W.M., Levinthal, D.A., 1990. Absorptive capacity: a new perspective on learning and innovation. Administrative Science Quarterly 35, 128-152.

Cooper, R., Edgett, S., Kleinschmidt, E., 2001. Portfolio management for new product development: results of an industry practices study. R\&D Management 31, 361-380. 
Corbett, A.C., Neck, H.M., DeTienne, D.R., 2007. How corporate entrepreneurs learn from fledgling innovation initiatives: cognition and the development of a termination script. Entrepreneurship Theory and Practice 31, 829-852.

Czarnitzki, D., 2005. The extent and evolution of productivity deficiency in Eastern Germany. Journal of Productivity Analysis 24, 211-231.

Czarnitzki, D., Hottenrott, H., 2009. Are local milieus the key to innovation performance? Journal of Regional Science 49, 81-112.

Czarnitzki, D., Kraft, K., 2006. R\&D and firm performance in a transition economy. Kyklos 59, 481-496.

Daft, R.L., Lengel, R.H., 1986. Organizational information requirements, media richness and structural design. Management Science 32, 554-571.

Damanpour, F., 2010. An integration of research findings of effects of firm size and market competition on product and process innovations. British Journal of Management 21, 996-1010.

Dawes, P.L., Massey, G.R., 2005. Antecedents of conflict in marketing's cross-functional relationship with sales. European Journal of Marketing 39, 1327-1344.

De Luca, L.M., Atuahene-Gima, K., 2007. Market knowledge dimensions and crossfunctional collaboration: examining the different routes to product innovation performance. Journal of Marketing 71, 95-112.

De Meyer, A.C.L., 1985. The flow of technological innovation in an R\&D department. Research Policy 14, 315-328.

De Visser, M., De Weerd-Nederhof, P., Faems, D., Song, M., Van Looy, B., Visscher, K., 2010. Structural ambidexterity in NPD processes: a firm-level assessment of the impact of differentiated structures on innovation performance. Technovation 30, 291299. 
Dilts, D.M., Pence, K.R., 2006. Impact of role in the decision to fail: an exploratory study of terminated projects. Journal of Operations Management 24, 378-396.

Dougherty, D., 1992. Interpretive barriers to successful product innovation in large firms. Organization Science 3, 179-202.

Eisenhardt, K., Tabrizi, B.N., 1995. Accelerating adaptive processes: product innovation in the global computer industry. Administrative Science Quarterly 40, 84-110.

Engwall, M., 2003. No project is an island: linking projects to history and context. Research Policy 32, 789-808.

Fritsch, M., Meschede, M., 2001. Product innovation, process innovation, and size. Review of Industrial Organization 19, 335-350.

Galbraith, J.K., 1952. A Theory of Price Control. Harvard University Press, Cambridge.

Galbraith, J.R., 1973. Organization Design. Addision-Wesley, Reading, MA.

Galbraith, J.R., 1974. Organization design: an information processing view. Interfaces 4, 2836.

García, N., Sanzo, M.J., Trespalacios, J.A., 2008. New product internal performance and market performance: evidence from Spanish firms regarding the role of trust, interfunctional integration, and innovation type. Technovation 28, 713-725.

Gebert, D., Boerner, S., Kearney, E., 2006. Cross-functionality and innovation in new product development teams: a dilemmatic structure and its consequences for the management of diversity. European Journal of Work and Organizational Psychology 15, 431-458.

Ghoshal, S., Korine, H., Szulanski, G., 1994. Interunit communication in multinational corporations. Management Science 40, 96-110.

Gibson, C.B., Gibbs, J.L., 2006. Unpacking the concept of virtuality: the effects of geographic dispersion, electronic dependence, dynamic structure, and national diversity on team innovation. Administrative Science Quarterly 51, 451-495. 
Gopalakrishnan, S., Bierly, P., Kessler, E.H., 1999. A reexamination of product and process innovations using a knowledge-based view. The Journal of High Technology Management Research 10, 147-166.

Green, S.G., Welsh, M.A., Dehler, G.E., 2003. Advocacy, performance, and threshold influences on decisions to terminate new product development. Academy of Management Journal 46, 419-434.

Greene, W.H., 2005. Econometric Analysis. Prentice Hall, New Jersey.

Griffin, A., 1997. PDMA research on new product development practices: updating trends and benchmarking best practices. Journal of Product Innovation Management 14, 429458.

Griffin, A., Hauser, J.R., 1992. Patterns of communication among marketing, engineering and manufacturing - a comparison between two new product teams. Management Science $38,360-373$.

Hansen, M.T., 2009. When internal collaboration is bad for your company. Harvard Business Review 87, 83-88.

Hendricks, K.B., Singhal, V.R., 2008. The effect of product introduction delays on operating performance. Management Science 54, 878-892.

Hise, R.T., O'Neal, L., Parasuraman, A., McNeal, J.U., 1990. Marketing/R\&D interaction in new product development: implications for new product success rates. Journal of Product Innovation Management 7, 142-155.

Iacovou, C.L., Dexter, A.S., 2005. Surviving IT project cancellations. Communications of the ACM 48, 83-86.

Jansen, J.J.P., Tempelaar, M.P., Van Den Bosch, F.A.J., Volberda, H.W., 2009. Structural differentiation and ambidexterity: the mediating role of integration mechanisms. Organization Science 20, 797-811. 
Kirner, E., Kinkel, S., Jaeger, A., 2009. Innovation paths and the innovation performance of low-technology firms - an empirical analysis of German industry. Research Policy 38, 447-458.

Klein, K.J., Sorra, J.S., 1996. The challenge of innovation implementation. Academy of Management Review 21, 1055-1080.

Koufteros, X.A., Vonderembse, M.A., Doll, W.J., 2002. Integrated product development practices and competitive capabilities: the effects of uncertainty, equivocality, and platform strategy. Journal of Operations Management 20, 331-355.

Love, J.H., Roper, S., 2009. Organizing innovation: complementarities between crossfunctional teams. Technovation 29, 192-203.

Martínez-Ros, E., 1999. Explaining the decisions to carry out product and process innovations: the Spanish case. The Journal of High Technology Management Research $10,223-242$.

Marwa, S., Zairi, M., 2008. An exploratory study of the reasons for the collapse of contemporary companies and their link with the concept of quality. Management Decision 46, 1342-1370.

McDonough, E.F., 1993. Faster new product development: investigating the effects of technology and characteristics of the project leader and team. Journal of Product Innovation Management 10, 241-250.

Menon, A., Chowdhury, J., Lukas, B.A., 2002. Antecedents and outcomes of new product development speed: an interdisciplinary conceptual framework. Industrial Marketing Management 31, 317-328.

Milliken, F.J., Martins, L.L., 1996. Searching for common threads: understanding the multiple effects of diversity in organizational groups. Academy of Management Review 21, $402-433$. 
Mishra, A.A., Shah, R., 2009. In union lies strength: collaborative competence in new product development and its performance effects. Journal of Operations Management 27, 324338.

Moenaert, R.K., Souder, W.E., 1996. Context and antecedents of information utility at the R\&D/marketing interface. Management Science 42, 1592-1610.

Nerkar, A., Roberts, P.W., 2004. Technological and product-market experience and the success of new product introductions in the pharmaceutical industry. Strategic Management Journal 25, 779-799.

OECD-Eurostat, 2005. Oslo Manual: Guidelines for Collecting and Interpreting Innovation Data, 3rd ed, OECD, Paris and Eurostat, Luxembourg.

Olson, E.M., Walker, O.C., Ruekert, R.W., Bonnerd, J.M., 2001. Patterns of cooperation during new product development among marketing, operations and R\&D: implications for project performance. Journal of Product Innovation Management 18, 258-271.

Perks, H., 2007. Inter-functional integration and industrial new product portfolio decision making: exploring and articulating the linkages. Creativity and Innovation Management 16, 152-164.

Pittaway, L., Robertson, M., Munir, K., Denyer, D., Neely, A., 2004. Networking and innovation: a systematic review of the evidence. International Journal of Management Reviews 5, 137-168.

Prajogo, D.I., Ahmed, P.K., 2006. Relationships between innovation stimulus, innovation capacity, and innovation performance. R\&D Management 36, 499-515.

Rammer, C., Czarnitzki, D., Spielkamp, A., 2009. Innovation success of non-R\&Dperformers: substituting technology by management in SMEs. Small Business Economics 33, 35-58. 
Rivers, D., Vuong, Q.H., 1988. Limited information estimators and exogeneity tests for simultaneous probit models. Journal of Econometrics 39, 347-366.

Roper, S., Du, J., Love, J.H., 2008. Modelling the innovation value chain. Research Policy 37, 961-977.

Shepherd, D.A., Cardon, M.S., 2009. Negative emotional reactions to project failure and the self-compassion to learn from the experience. Journal of Management Studies 46, 923949.

Shepherd, D.A., Kuratko, D.F., 2009. The death of an innovative project: how grief recovery enhances learning. Business Horizons 52, 451-458.

Sheremata, W.A., 2000. Centrifugal and centripetal forces in radical new product development under time pressure. Academy of Management Review 25, 389-408.

Song, M., Dyer, B., Thieme, R.J., 2006. Conflict management and innovation performance: an integrated contingency perspective. Journal of the Academy of Marketing Science 34, 341-356.

Song, M., Montoya-Weiss, M.M., Schmidt, J.B., 1997. Antecedents and consequences of cross-functional cooperation: a comparison of $\mathrm{R} \& \mathrm{D}$, manufacturing, and marketing perspectives. Journal of Product Innovation Management 14, 35-47.

Staiger, D., Stock, J.H., 1997. Instrumental variables regression with weak instruments. Econometrica: Journal of the Econometric Society 65, 557-586.

Stifterverband, 2010. FuE-Datenreport 2010. Wissenschaftsstatistik GmbH im Stifterverband für die Deutsche Wirtschaft, Essen.

Subrahmanya, B., 2005. Pattern of technological innovations in small enterprises: a comparative perspective of Bangalore (India) and Northeast England (UK). Technovation 25, 269-280. 
Swink, M., Song, M., 2007. Effects of marketing-manufacturing integration on new product development time and competitive advantage. Journal of Operations Management 25, 203-217.

Tatikonda, M.V., Montoya-Weiss, M.M., 2001. Integrating operations and marketing perspectives of product innovation: the influence of organizational process factors and capabilities on development performance. Management Science 47, 151-172.

Tatikonda, M.V., Rosenthal, S.R., 2000a. Successful execution of product development projects: balancing firmness and flexibility in the innovation process. Journal of Operations Management 18, 401-425.

Tatikonda, M.V., Rosenthal, S.R., 2000b. Technology novelty, project complexity, and product development project execution success: a deeper look at task uncertainty in product innovation. IEEE Transactions on Engineering Management 47, 74-87.

Tessarolo, P., 2007. Is integration enough for fast product development? An empirical investigation of the contextual effects of product vision. Journal of Product Innovation Management 24, 69-82.

Troy, L.C., Hirunyawipada, T., Paswan, A.K., 2008. Cross-functional integration and new product success: an empirical investigation of the findings. Journal of Marketing 72, 132-146.

Tushman, M.L., Nadler, D.A., 1978. Information processing as an integrating concept in organizational design. Academy of Management Review 3, 613-624.

Weick, K.E., 1979. The Social Psychology of Organizations. Addison-Wesley, Reading, MA.

West, J., 2000. Institutions, information processing, and organization structure in research and development: evidence from the semiconductor industry. Research Policy 29, 349373. 
Wooldridge, J.M., 2002. Econometric Analysis of Cross Section and Panel Data. MIT Press, Cambridge.

Xie, J., Song, X.M., Stringfellow, A., 1998. Interfunctional conflict, conflict resolution styles, and new product success: a four-culture comparison. Management Science 44, 192206.

Zeller, C., 2002. Project teams as means of restructuring research and development in the pharmaceutical industry. Regional Studies 36, 275-289. 


\section{TABLES}

\section{Table 1: Descriptive Statistics}

\begin{tabular}{|c|c|c|c|c|c|c|}
\hline & \multicolumn{2}{|c|}{$\begin{array}{l}\text { Collaborating } \\
\text { firms }\end{array}$} & \multicolumn{2}{|c|}{$\begin{array}{l}\text { Non-collaborating } \\
\text { firms }\end{array}$} & \multirow{2}{*}{\multicolumn{2}{|c|}{$\begin{array}{l}\text { mean } \\
\text { difference }^{\mathrm{A}}\end{array}$}} \\
\hline & mean & std. err. & mean & std. err. & & \\
\hline$\%$ sales from products new to the market & 6.59 & 15.50 & 5.29 & 12.92 & 1.30 & \\
\hline$\%$ sales from products new to the firm & 25.82 & 29.84 & 22.86 & 28.49 & 3.06 & \\
\hline$\%$ sales from quality improvements & 3.15 & 6.67 & 1.06 & 3.57 & 2.09 & $* *$ \\
\hline$\%$ cost reductions & 4.60 & 11.01 & 2.52 & 6.00 & 2.08 & $* *$ \\
\hline $\log ($ sales from products new to the market) & 2.45 & 3.31 & 2.07 & 3.05 & 0.38 & \\
\hline $\log$ (sales from products new to the firm) & 5.18 & 3.65 & 4.51 & 3.49 & 0.67 & $*$ \\
\hline $\log$ (sales from quality improvements) & 1.18 & 3.13 & 0.04 & 2.47 & 1.14 & $* * *$ \\
\hline $\log ($ cost reductions $)$ & 2.28 & 3.27 & 1.59 & 3.00 & 0.69 & $* *$ \\
\hline Innovation project delay & 0.57 & 0.50 & 0.08 & 0.27 & 0.49 & $* * *$ \\
\hline Innovation project termination & $\begin{array}{l}0.33 \\
511.4\end{array}$ & $\begin{array}{l}0.47 \\
1210.5\end{array}$ & 0.02 & 0.14 & 0.31 & $* * *$ \\
\hline Employment & $\begin{array}{l}8 \\
106.7\end{array}$ & 1 & 346.07 & 774.63 & 165.41 & \\
\hline $\mathrm{R} \& \mathrm{D}$ & 0 & 817.26 & 5.32 & 20.13 & 101.38 & \\
\hline R\&D/total sales & 3.68 & 4.66 & 3.16 & 2.96 & 0.52 & \\
\hline Age & 35.50 & 40.98 & 31.03 & 38.28 & 4.47 & \\
\hline East Germany & 0.34 & 0.47 & 0.38 & 0.49 & -0.04 & \\
\hline Part of a firm group & 0.47 & 0.50 & 0.86 & 0.35 & -0.39 & $* * *$ \\
\hline$\%$ sales with most important product & 69.29 & 23.61 & 72.17 & 12.39 & -2.88 & \\
\hline $\begin{array}{l}\% \text { of R\&D employees outside the R\&D } \\
\text { department }\end{array}$ & 2.23 & 0.94 & 0.09 & 0.51 & 2.14 & $* * *$ \\
\hline Number of observations & 141 & & 292 & & & \\
\hline
\end{tabular}


Table 2: Probit Models for Costs of Inter-departmental Collaboration

\begin{tabular}{|c|c|c|c|c|}
\hline Dependent Variable & Delay & Termination & Delay & Termination \\
\hline Model & probit & probit & iv probit & iv probit \\
\hline & $\begin{array}{l}\text { coeff. } \\
\text { (std. err.) }\end{array}$ & $\begin{array}{l}\text { coeff. } \\
\text { (std. err.) }\end{array}$ & $\begin{array}{l}\text { coeff. } \\
\text { (std. err.) }\end{array}$ & $\begin{array}{l}\text { coeff. } \\
\text { (std. err.) }\end{array}$ \\
\hline Collaboration & $\begin{array}{l}1.60 * * * \\
(0.19)\end{array}$ & $\begin{array}{l}1.70 * * * \\
(0.27)\end{array}$ & $\begin{array}{l}1.97 * * * \\
(0.43)\end{array}$ & $\begin{array}{l}1.19 * * \\
(0.60)\end{array}$ \\
\hline Log(employment) & $\begin{array}{l}-0.38 * \\
(0.21)\end{array}$ & $\begin{array}{l}-0.36^{*} \\
(0.21)\end{array}$ & $\begin{array}{l}-0.40^{*} \\
(0.21)\end{array}$ & $\begin{array}{l}-0.32 \\
(0.22)\end{array}$ \\
\hline $\log (\text { employment })^{2}$ & $\begin{array}{l}0.05 * * \\
(0.02)\end{array}$ & $\begin{array}{l}0.04^{*} \\
(0.02)\end{array}$ & $\begin{array}{l}0.04 * * \\
(0.02)\end{array}$ & $\begin{array}{l}0.04 * \\
(0.02)\end{array}$ \\
\hline R\&D intensity & $\begin{array}{l}0.03 * \\
(0.02)\end{array}$ & $\begin{array}{l}0.02 \\
(0.02)\end{array}$ & $\begin{array}{l}0.03 \\
(0.02)\end{array}$ & $\begin{array}{l}0.02 \\
(0.02)\end{array}$ \\
\hline East Germany & $\begin{array}{l}-0.56^{* * * *} \\
(0.16)\end{array}$ & $\begin{array}{l}-0.23 \\
(0.18)\end{array}$ & $\begin{array}{l}-0.54 * * * \\
(0.16)\end{array}$ & $\begin{array}{l}-0.24 \\
(0.17)\end{array}$ \\
\hline Part of a firm group & $\begin{array}{l}0.02 \\
(0.16)\end{array}$ & $\begin{array}{l}0.25 \\
(0.18)\end{array}$ & $\begin{array}{l}0.19 \\
(0.25)\end{array}$ & $\begin{array}{l}0.05 \\
(0.27)\end{array}$ \\
\hline $\log ($ age $)$ & $\begin{array}{l}-0.16^{* *} \\
(0.08)\end{array}$ & $\begin{array}{l}-0.02 \\
(0.08)\end{array}$ & $\begin{array}{l}-0.15^{*} \\
(0.08)\end{array}$ & $\begin{array}{l}-0.03 \\
(0.08)\end{array}$ \\
\hline Share of sales with main product & $\begin{array}{l}-0.01 * \\
(0.00) \\
(0.63)\end{array}$ & $\begin{array}{l}-0.00 \\
(0.00) \\
(0.67) \\
\end{array}$ & $\begin{array}{l}-0.01 \\
(0.00) \\
(0.69) \\
\end{array}$ & $\begin{array}{l}-0.00 \\
(0.00) \\
(0.74) \\
\end{array}$ \\
\hline Number of observations & 433 & 433 & 433 & 433 \\
\hline Loglikelihood & -220.28 & -188.57 & -433.36 & -401.56 \\
\hline
\end{tabular}

Four industry dummies are included but not reported.

$* * *, * *, *$ indicate statistical significance at the $1 \%-, 5 \%-, 10 \%$ level. 
Table 3: Heteroscedastic Tobit Models for Innovation Outcome

\begin{tabular}{|c|c|c|c|c|}
\hline & \multicolumn{2}{|c|}{ Sales } & Sales & $\begin{array}{c}\text { Cost } \\
\text { reduction }\end{array}$ \\
\hline & \multicolumn{2}{|c|}{ Product related innovations } & \multicolumn{2}{|c|}{ Process related innovations } \\
\hline Dependent variable & $\begin{array}{l}\log \text { (products new } \\
\text { to the market) }\end{array}$ & $\begin{array}{l}\log \text { (products new } \\
\text { to the firm) }\end{array}$ & $\begin{array}{l}\log \text { (quality } \\
\text { improvements) }\end{array}$ & $\begin{array}{l}\log (\operatorname{cost} \\
\text { reduction })\end{array}$ \\
\hline & $\begin{array}{l}\text { coeff. } \\
\text { (std. err.) }\end{array}$ & $\begin{array}{l}\text { coeff. } \\
\text { (std. err.) }\end{array}$ & $\begin{array}{l}\text { coeff. } \\
\text { (std. err.) }\end{array}$ & $\begin{array}{l}\text { coeff. } \\
\text { (std. err.) }\end{array}$ \\
\hline Collaboration & $\begin{array}{l}0.33 \\
(0.30)\end{array}$ & $\begin{array}{l}0.12 \\
(0.37)\end{array}$ & $\begin{array}{l}3.54 * * * \\
(1.17)\end{array}$ & $\begin{array}{l}2.20 * * \\
(1.05)\end{array}$ \\
\hline Delay & $\begin{array}{l}-0.18 \\
(0.27)\end{array}$ & $\begin{array}{l}0.34 \\
(0.33)\end{array}$ & $\begin{array}{l}0.70 \\
(0.92)\end{array}$ & $\begin{array}{l}-0.43 \\
(0.94)\end{array}$ \\
\hline Termination & $\begin{array}{l}0.37 \\
(0.31)\end{array}$ & $\begin{array}{l}0.46 \\
(0.38)\end{array}$ & $\begin{array}{l}-0.37 \\
(1.08)\end{array}$ & $\begin{array}{l}0.23 \\
(0.99)\end{array}$ \\
\hline Log(employment) & $\begin{array}{l}0.44 * * * \\
(0.08)\end{array}$ & $\begin{array}{l}0.85^{* * *} \\
(0.10)\end{array}$ & $\begin{array}{l}-0.24 \\
(0.39)\end{array}$ & $\begin{array}{l}1.24 * * * \\
(0.35)\end{array}$ \\
\hline R\&D intensity & $\begin{array}{l}0.08 * * * \\
(0.03)\end{array}$ & $\begin{array}{l}0.06 * * \\
(0.03)\end{array}$ & $\begin{array}{l}-0.03 \\
(0.10)\end{array}$ & $\begin{array}{l}-0.03 \\
(0.08)\end{array}$ \\
\hline East Germany & $\begin{array}{l}-0.21 \\
(0.25)\end{array}$ & $\begin{array}{l}0.09 \\
(0.32)\end{array}$ & $\begin{array}{l}2.44 * * \\
(0.96)\end{array}$ & $\begin{array}{l}-1.76^{*} \\
(0.95)\end{array}$ \\
\hline Part of a firm group & $\begin{array}{l}0.29 \\
(0.28)\end{array}$ & $\begin{array}{l}0.53 \\
(0.34)\end{array}$ & $\begin{array}{l}-1.46 \\
(1.05)\end{array}$ & $\begin{array}{l}-0.48 \\
(0.90)\end{array}$ \\
\hline Log(age) & $\begin{array}{l}0.09 \\
(0.14)\end{array}$ & $\begin{array}{l}-0.12 \\
(0.17)\end{array}$ & $\begin{array}{l}0.37 \\
(0.53)\end{array}$ & $\begin{array}{l}0.49 \\
(0.45)\end{array}$ \\
\hline $\begin{array}{l}\text { Share of sales with } \\
\text { main product }\end{array}$ & $\begin{array}{l}-0.00 \\
(0.01)\end{array}$ & $\begin{array}{l}-0.01 \\
(0.01)\end{array}$ & $\begin{array}{l}0.03 \\
(0.02)\end{array}$ & $\begin{array}{l}0.04 * \\
(0.02)\end{array}$ \\
\hline Constant & $\begin{array}{l}-1.49 * \\
(0.78)\end{array}$ & $\begin{array}{l}-0.09 \\
(0.98)\end{array}$ & $\begin{array}{l}-10.31 * * * \\
(3.41)\end{array}$ & $\begin{array}{l}-13.63 * * * \\
(3.32)\end{array}$ \\
\hline $\begin{array}{l}\text { Test for } \\
\text { homoscedasticity }\end{array}$ & $\begin{array}{l}\mathrm{X}^{2}= \\
104.99 * * *\end{array}$ & $\begin{array}{l}X^{2}= \\
48.16 * * *\end{array}$ & $\begin{array}{l}\mathrm{X}^{2}= \\
19.90 * * *\end{array}$ & $\begin{array}{l}\mathrm{X}^{2}= \\
8.41\end{array}$ \\
\hline $\begin{array}{l}\text { Number of observations } \\
\text { Loglikelihood }\end{array}$ & $\begin{array}{l}433 \\
-1029.46\end{array}$ & $\begin{array}{l}433 \\
-965.11\end{array}$ & $\begin{array}{l}433 \\
-513.78\end{array}$ & $\begin{array}{l}433 \\
-648.12\end{array}$ \\
\hline
\end{tabular}

4 industry dummies are included but not reported.

The heteroscedasticity term contains 3 size class and 4 industry dummies.

$* * *, * *, *$ indicate statistical significance at the $1 \%-, 5 \%-, 10 \%$ level. 